\title{
E-Játékosítás a rekreáció szolgálatában E-Gamification in the Service of Recreation
}

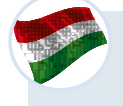

ÖSSZEFOGLALÁS:

Bevezetés

$\mathrm{Az}$ okos eszközök beépülése a hétköznapokba természetesen a sport- és szabadidőpiac egyik szegmensét sem hagyta érintetlenül. A tanulmány az okoseszközök segítségével végzett rekreációs programok sajátosságaira és a bennük rejlő lehetőségekre reflektál, elsősorban szakirodalom, másodsorban szakmai, gyakorlati tapasztalatok alapján. A téma aktualitását egyfelől a fizikai inaktivitás továbbra is fennálló problémája, másfelől pedig az okoseszközök elterjedtsége és az inaktivitásban tulajdonított szerepe adja. Ezekre az eszközökre tervezett „szórakoztató, oktató” programok kiváló eszközként szolgálhatnak a rekreáció bármely területén.

Célkitúzések

A két csoport tagjai (30 fó) egy környezettudatosságra alapozó, GPS alapú, kvízkérdések beépítésével létrehozott pontvadász játékon vettek részt, melyet saját okostelefonjaikon futtattak. A tiszta játékidő/részvételi idő 35 perc volt. A játékosok helyzeti és mozgási adatait a készülékekbe épített, automatizáltan adatokat gyűjtő helymeghatározó rendszer biztosította, mely mára legalább 8-10 méteres pontossággal képes meghatározni a tulajdonosának pontos földrajzi helyzetét. A program végén a GPS segítségével mért helyadatokból kiszámolt távolságokat a készülékek automatikusan feltöltötték a szerverre, ahol egy grafikonon jelentek meg.

Eredmények

A jól megtervezett játék és helyszín segítségével a GPS alapú automatizált adathalászat alapján a játékosok átlagosan 4,8 kilométert tettek meg változó tempóban. $A 35$ perces játékok alatt, különböző sebességgel megtett 5000-6000 lépés meghaladja a világon mérhető napi lépésszám átlagát.

\section{Következtetések}

A játékosítás eszközeivel, a játékra való motivációt kihasználva ezen eszközöket a fizikai és szellemi rekreáció szolgálatába tudjuk állítani, mindezt úgy, hogy a résztvevő szinte észre szem veszi, hogy mennyit mozog egy-egy szellemileg is kihívást jelentő program alatt. Ha figyelembe vesszük a játék nyújtotta motivációs tényezőket, kombináljuk őket a sikeres játékok alapelemeivel és mindeközben játékos vetélkedést tudunk kialakítani azzal, a mai „kijelzőgörgetőket” is mozgásra tudjuk bírni.

Kulcsszavak: gamifikáció, okoseszközök, infokommunikációs technológia, egészségvédő testmozgás

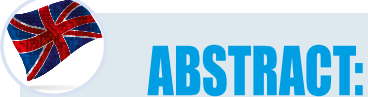

\section{Introduction}

Naturally the integration of smart devices into our everyday lives has not left any part of the sports- and leisure time market unaffected. This study, based firstly on academic references and secondly on professional, pragmatical experience focuses on the main characteristics of smart device assisted recreational programs and reflects on the hidden possibilities within them. The actuality of this topic is supported on one hand by our current state of physical inactivity and on the other hand by the widespread use of smart devices and their attributed role in this inactivity. The "entertaining, educational" programs developed for these devices are perfect tool for any recreational field.

\section{Objectives}

Members of the two groups (30 persons) took part in a green attitude-, gps based point collecting game with quiz-like elements, which they participated in with their smartphones. The clear playing/participation time was 35 minutes. The player's position and movement data is tracked by the device's built-in positioning system, which can determine the exact geographical position of its owner with an accuracy of 8-10 meters and automatically collects data. At the end of the program, the distances calculated from the location data measured using GPS were automatically uploaded to the server by the devices, where they appeared on a graph.

Results

Based on the collected GPS data and utilizing a well designed game and optimal location the participants on average traveled around $4,8 \mathrm{~km}-\mathrm{s}$ in varying paces. The $5000-6000$ steps during the course of this 35 minute game exceed the average daily number of steps measured in the world.

Conclusions

With the tools of gamificaiton and using peoples motivation to play we can utilize these components in the service of physical and mental recreation in a way that the participants barely even notice how much they excercise during a mentally challenging program. If we consider the motivational factors offered by te game, combine them with the baseline elements of succesful games and we are able to create playful competition on top of it, we would be able to make today's "display scrollers" move as well.

Key words: gamification, smart devices, infocommunication technology, healthy excercise 


\section{BEVEZTES}

Azt látjuk és tapasztaljuk (legtöbben sajnos saját magunkon is), hogy modern, XXI-ik századi világunkban az ülő életmód egyértelműen dominál. A minket körülvevő technikai eszközök annyi és olyan intenzitásban bombáznak minket ingerekkel, hogy szinte lehetetlen versenyre kelni velük a hagyományos módszerekkel. Az évek folyamán ezek az eszközök folyamatosan fejlődtek, és újabb és újabb funkciókkal láttuk el őket. Direkt és indirekt módon az élet közel minden területén függővé váltunk ezektől az eszközöktől. Azonban egy dolgot nem tanultunk meg; ezen eszközök ésszerü, jó felhasználását, és ennek sok esetben már - orvosi kutatások által bizonyított fizikai elváltozásokat előidéző hatásuk is van. Az ujjak ínhüvelygyulladását (Kishore et al, 2019) és az ízület rendellenes tartását, nyak és vállöv izmainak és ízületeinek változását (Kahattak et al, 2019, Damodaran et al. 2018). Egy átlagos felhasználó éppen csak egy-két dologra használja őket, és a közelében sincs annak, hogy kiaknázza a bennük rejlő lehetőségeket.

\section{MOBL ESZYOZZÖK}

A cikk elején említett folyamatos technikai fejlődés egyértelmű következménye, hogy mára Magyarországon több mint 5,3 millióan használunk okostelefont. Az okostelefon életünkben betöltött kimagasló szerepét nemcsak a használók számának folyamatos emelkedése, de a készülékünkhöz való ragaszkodással kapcsolatos kutatások is bizonyítják. Amellett, hogy az okostelefon-tulajdonosok 71 százaléka szinte sosem kapcsolja ki telefonját, 55 százalék éjszaka is maga mellett tartja, negyedük pedig még a mellékhelyiségbe is magával viszi azt. 2018 elején több mint 4 milliárd internetfelhasználót jegyeztek világszerte, vagyis már az emberek többsége, 53 százaléka csatlakozik valamilyen módon a világhálóra. 49 százalék ráadásul már részben vagy kizárólagosan mobil adatkapcsolatot is igénybe vesz.

Az eredményekból jól láthatjuk, hogy a digitalizáció egy lépésre került attól, hogy az online felhasználásban is abszolút többséget szerezzen a mobil platform. Ezeket a „potenciális” célpontokat van lehetőségünk elérni és felhívni a figyelmüket az újfajta lehetőségek használatára, úgy is fogalmazhatnánk, hogy a készülékeiket a mi szolgálatunkba állítsuk, mely igazából az ő egészségükre gyakorolhat pozitív hatást (bitriport, 2018).

A fejlődés következtében azonban ezeknek a lehetőségeknek a tárháza sokkal szélesebb, mint azt a legtöbben gondolnánk. Ezeket a kiaknázatlan lehetőségeket az élet több frontján is a szolgálatunkba állíthatjuk, mégpedig úgy, hogy a már megszerzett tudásunkat és tapasztalatunkat megpróbáljuk modern köntösbe bújtatni. Az eszközök fejlődése lehetővé tette, hogy ma már szinte mindenki zsebében (de fóleg kezében) ott lapul valamilyen mobil, okoseszköz.

Rekreációs szakember szemével nézve a társadalmunkat célunk az, hogy a rekreáció eszközeivel az emberek életminő-

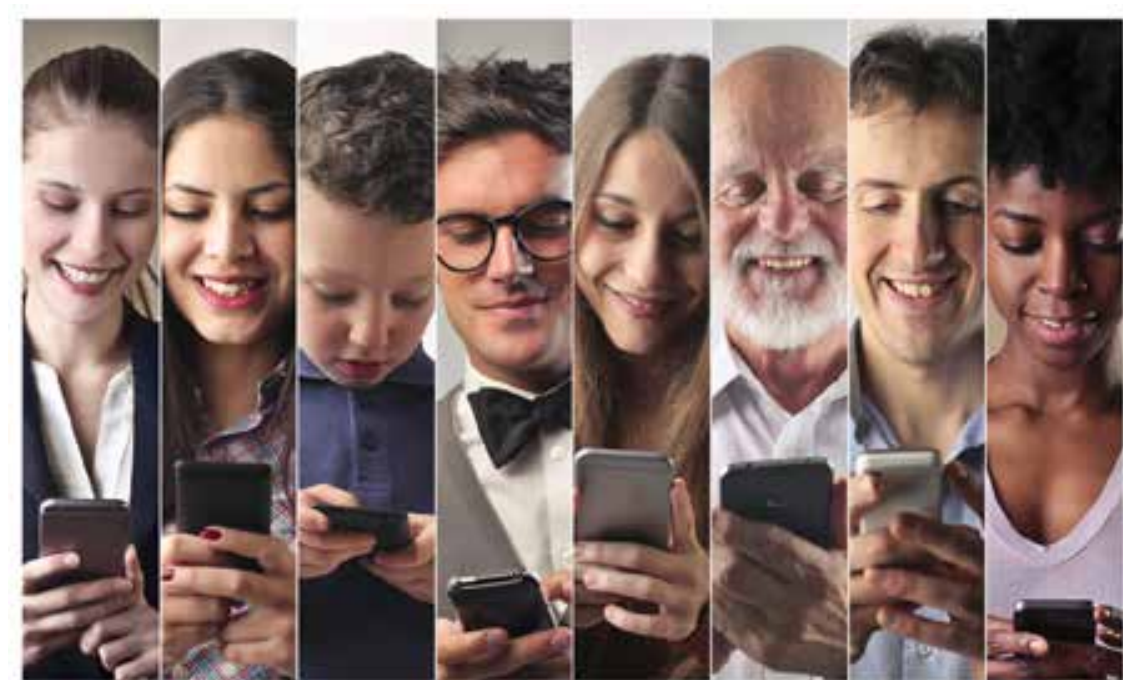

ségén javítsunk; segítsünk abban, hogy munkavégző képességük helyreálljon vagy éppen minőségi szabadidő-eltöltési lehetőségekkel találkozzanak. A rekreációs tevékenység megítélése, értelmezése és értékelése elsősorban célja alapján lehetséges. A tevékenység jellegének (és eszközének) dominanciája szerint feloszthatjuk szellemi és fizikai (mozgásos) rekreációra (Kovács, 2004). Mára ez a definíció felfrissült; A rekreáció szabadidóben, a tevékeny pihenés érdekében végzett minden olyan szellemi és mozgásos tevékenység, melyet a napi fó elfoglaltság által okozott fáradtság, feszültség feloldása, a testi-lelki -szellemi teljesítóképesség helyreállítása, fokozása érdekében tesz az ember (Fritz, 2011). A két terület közötti határvonal nagyon vékony, hiszen ha sorba vesszük a fizikai mozgásformákat, megállapíthatjuk, hogy mindegyik hatással van szellemi felfrissülésünkre, mentális állapotunkra. Az emberi teljesítőképesség megóvásának, fejlesztésének fontos feltétele a mindennap életvitel keretében megvalósuló szellemi és fizikai rekreáció. Ennek lényege, hogy a megélhetés aktuális forrását jelentő, többnyire egyirányú, gyakran monoton és megerőltetó igénybevételt ellensúlyozza, és a lehetőségekhez képest ápolja, funkcióképes állapotban tartsa a már megszerzett készségeket, képességeket, őrizze az egyén adaptációs készségét, ellenálló képességét. E kívánalmaknak korántsem felel meg az a korábban széles körben propagált teória, miszerint a fizikai foglalkozásúak döntően szellemi tevékenységek révén, a szellemi foglalkozásúak pedig alapvetően fizikai aktivitással teremthetik meg a szervezet számára kívánatos egyensúlyt (Fritz, 2019).

Mindkét területen szükség van az újabb és újabb impulzusokra, hiszen a modern eszközök által nyújtott ingergazdag környezetet nem egyszerü felülmúlni. Mint azt említettük, a szellemi és fizikai rekreáció között az esetek többségében elég keskeny a határvonal, hiszen ha valamilyen fizikai aktivitást végzünk, azt azért végezzük, mert az szellemileg is frissítően hat majd ránk, és ugyanígy a szellemi rekreáció kategóriájába sorolható tevékenységek bár részben passzívak, zömükben mégis aktívak, hiszen ezek egy része valamilyen testmozgást is magával hordoz.

A modern technikai eszközöket az em- berek mindkét „cél” elérése érdekében használják. Hiszen a jobb hozzáállású felhasználók jó esetben éppúgy naplózzák a sporttevékenységüket (akár folyamatosan versengve egymással), mint ahogy szókeresőznek vagy mahjongoznak abban a napi pár „magányos percükben”. Azonban a legjellemzőbb minta, amit mi is megfigyelhetünk, az a folyamatos kijelző „görgetés”. Hányszor kapjuk válaszként a „Mit csinálsz?” kérdésünkre, a „Ja, semmit, csak görgetem a.... (mindenki helyettesítse be az éppen csúcson lévő valamilyen közösségi média alkalmazást). Ez a válasz elhangozhat bárhol, bármilyen szituációban indoor és outdoor környezetben is. Az eszközök fejlődése lehetővé tette, hogy adott a lehetôség majdnem mindenkinél, hogy ezeket az embereket elérjük a készülékeken keresztül és oly módon ne fosszuk meg őket a „kütyü-élménytől”, hogy mégis felfrissüljenek szellemileg és fizikálisan is.

Vajon milyen eszközeink lehetnek arra, amelyek évszázadok óta múködnek, új távlatokat nyithatnánk a Rekreációban, és mégsem használjuk őket eléggé? Ahhoz azonban, hogy a kellő hatást érjük el, már egészen fiatal korban hozzá kell szoktatnunk a felhasználókat, hogy az eszközök hogyan használhatók átgondoltan, jó célokra. Jelen tanulmány célja, hogy bemutassa a modern infokommunikációs eszközök rekreatív mobilizálásra alkalmazható hatásait a megfelelő programok kialakításával.

\section{A JÁTÉKKOSITT́́SP}

Mivel a generációk életében a játék mindig is kifejezetten fontos szerepet töltött be, így az önkifejezés ezen eszköze a mobiltelefonok világát sem kerülhette el. A gamifikáció nagyon divatos kifejezéssé vált az elmúlt évek folyamán. De, mit is értünk gamifikáción avagy játékosításon? Az emberek motiválása játékok múködési mechanizmusainak, játékelemeinek a felhasználásával valamilyen munkához, tanuláshoz, tehát nem játékhoz kötődő cél elérése érdekében. A gamifikáció egyfajta ösztönző, motiváló rendszer kialakítására utal (Sztanáné, 2017). Olyan folyamatokat szoktunk gamifikálni, amiken mi szeretnénk, hogy az emberek végigmenjenek, de ők nem éreznek erőteljes késztetést erre. 


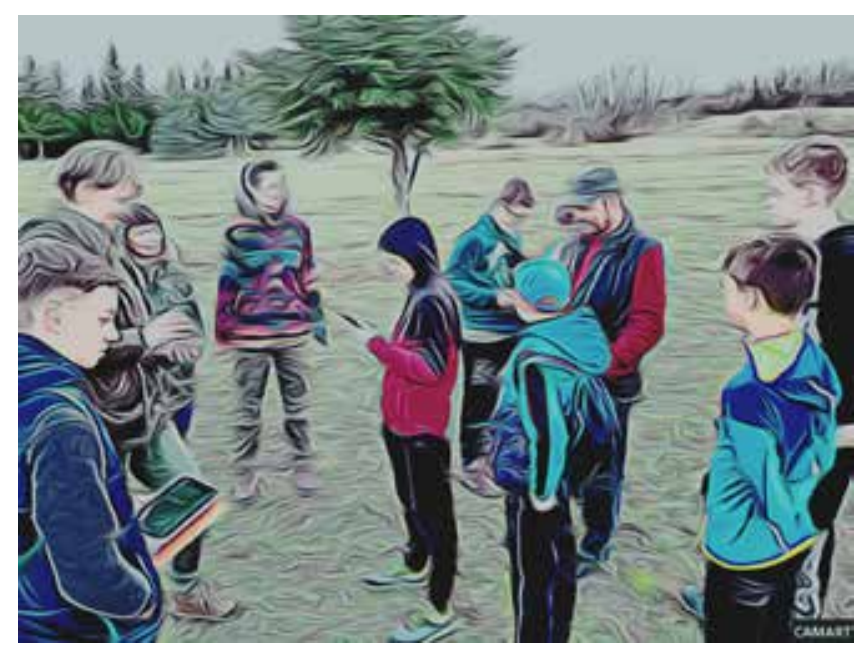

Tehát a gamifikáció a motiválás egyik módszere, amelyet mi, rekreátorok kellő körültekintéssel használva jobb életminőséget érhetünk el, anélkül, hogy azt a résztvevők fejlesztésként élnék meg.

\section{JUÁTÉK ÉS MOTIUÍCIÓ}

Az emberiség történetében a Játék mindig is kifejezetten fontos szerepet töltött be, gondoljunk csak bele, az egészen kis gyermekek is a játékok segítségével tudnak beilleszkedni később a társadalmunkba. Számukra a játék az önkifejezés eszköze, amelyen keresztül mi is megfigyelhetjük óket (Sztanáné, 2017). Nem mindegy azonban, hogy milyen játékokat játszanak. A mai okoseszközökön elérhető népszerü játékok nagy része csupán lenyügöző grafikájával és akciódus jeleneteivel „szívja magába” a gyerekeket. Létesznek edukációs jellegü, logikai játékok is, de ezeknél a megjelenés általában másodlagos szerepet tölt be, így miután nem tudják az „eye-candy” hatást elérni, csak a kispadon ülnek a cserére várva a Play Áruházban vagy éppen az Appstore-ban. A játékosok minden játékban el szeretnének érni valamilyen fiktív vagy valós célt, és ennek érdekében tele vannak motivációval. Mit is jelent valójában a motiváció?

Motiváltnak lenni azt jelenti, hogy késztetést érzünk, hogy valamit megtegyünk. Ennek ellentettje, mikor lendület és inspiráció hiányában motiválatlannak tekintjük a személyt (Ryan - Deci, 200ob). A külső és belső behatások megszabják motivációs szintünket. Motivációnk különböző irányultságú lehet: egy tanuló kíváncsiságából fakadóan - rendkívül motivált lehet házi feladatának elvégzése során, de ugyanezt eredményezheti az az igénye is, hogy tanára elvárásainak megfeleljen. A játékok és játékosítás segítségével azt próbáljuk meg elérni, hogy a motiváció egy lehetőleg állandó, magasabb szinten legyen jelen.

Tudományos kutatások és értekezések alapján leggyakrabban a motivációk két nagy csoportját különböztetjük meg (Ryan - Deci, 200ob). Intrinzik (belső) motivációról beszélünk, amikor valamit azért teszünk, mert magát a tevékenységet érdekesnek vagy élvezetesnek találjuk, illetve extrinzik (külső) motiváltság esetén a tevékenységünket valamilyen kedvező eredmény, pozitív következmény vezérli. A jól megtervezett és kivitelezett játékok segítségével mindkét típusra sikeresen tudunk hatni, ezzel folyamatosan fenntartva a motivációs szintet. Alapvetően az embereket intrinzik motiváció hajtja, azonban mivel nincs két egyforma ember, mások ugyanezt a tevékenységet nem élik meg ösztönzően. Nincs olyan tevékenység, amire egy közösség vagy társadalom tagjai belsóleg egyformán motiváltak lennének, és ez igaz a játékosított tartalmakra is (Ryan - Deci, 200ob).

Ha a játékok mögötti motivációt kellene vizsgálnunk, akkor két jelentős, modern motivációs elméletet mindenképpen érdemes figyelembe vennünk: az Öndeterminációs elméletet és a Flow (Áramlat) elméletet.

\section{ÖNDETERTIVÍGCĹS ELMÉLET}

Az Öndeterminációs elmélet (Ryan - Deci, 2000a) szerint a magas fokú motiváció és elköteleződés feltételei az autonómia, a kompetencia és a másokhoz tartozás. Ezek együttes megléte fokozza a teljesítményt, a kitartást és a kreativitást.
Ha ezen feltételek bármelyike nem adott egy bizonyos helyzetben, az jelentős negatív hatást gyakorol jóllétünkre. Az Öndeterminációs elmélet az olyan emberi viselkedéseket, mint az agreszszió vagy a diszkrimináció, a fenti alapvető szükségletek hiányára való reakcióként értelmezi.

A Kognitív Értékelési Elmélet (Ryan - Deci, 200ob), az Öndeterminációs Elmélet részeként, a társas helyzetek azon faktorait határozza meg, amelyekkel az intrinzik motivációban bekövetkező változékonyság magyarázható. Az elmélet szerint a személyközi események és azok jellemzői, mint például a jutalmazás, kommunikáció vagy a visszajelzés, a kompetencia érzését erősítik egy adott tevékenyég kapcsán, ezzel növelve intrinzik motivációnkat. Ezzel összhangban, a megfelelő kihívások, a hatékonyság elősegítését szolgáló visszajelzések és a becsmérlő értékelésektől mentes közeg az intrinzik motiváció emelkedését eredményezi. A kompetencia önmagában azonban nem vezet fejlődéshez, ha az autonómia igénye sérül.

\section{AFLOWÉLLÉNY ELMÉELTE}

Csíkszentmihályi (1997) Flow elmélete szerint, ha a tudatba áramló információ összeegyeztethető a célokkal, akkor a pszichotikus energia erőfeszítés nélkül áramlik bennünk. A flowélményt elősegítő tevékenységek autotelikus, önmagukért való tevékenységek: miközben benne vagyunk, magára a tevékenységre figyelünk, nem pedig a következményére.

A flowélmény keletkezésének alapvető feltételei a világos cél, az azonnali visszacsatolás, valamint egy olyan feladat, amelynek megoldásához meg van a kellő jártasságunk, de nem találjuk könynyünek (Dweck - Eliot, 2005).

A flowélményt nagyfokú összpontosítás, a tevékenység feletti uralom érzése, a tevékenység és a tudatosság összeolvadása jellemzi (Nakamura és Csíkszentmihályi, 2002). Saját magunk észlelése megszűnik. Időészlelésünk megváltozik, általában rövidebbnek érezzük az eltelt időt. A tevékenységet magát jutalomértékűnek éljük meg.

A társas tevékenységek szintén flow tevékenységekké válhatnak (Hektner et al., 2007). Ezekben a helyzetekben a másik ember a környezet részeként támogathatja a flowélmény fenntartását: kihívást adhat, vagy visszajelezhet teljesítményünkkel kapcsolatban.

\section{RIVER CTTY, AVAGY A JÁTEKOSITÁS MÚKÖDIKI}

Ennek bizonyításához térjünk vissza 2005-be, az első kutatások egyikéhez. Bár példánk nem az „e-világból” érkezik, mégis tökéletesen ábrázolja azt, hogy a játékosítás milyen fontos szerepet játszhat életünkben.

A River City című játék a tudományos gondolkodás eszköztárának elsajátítását célozza meg, elsősorban kevés elköteleződést mutató, alacsony színvonalon teljesítő diákok számára (Nelson et al., 2005). A játék során a gyerekek azt gyakorolják, hogyan viselkedik egy tudós: együttmúködésben azonosítanak problémákat, megfigyelnek, következtetnek, hipotéziseket alkotnak és tesztelnek, majd ezek alapján vonnak le következtetéseket a jelenség lehetséges okairól.

A River City virtuális világát egy város és a várost keresztülszelő folyó alkotja. A képzeletbeli városban csakúgy, mint a való életben, számos intézmény és épület található. Egyetemek, kórházak, lakóházak, boltok stb. A saját valós környezetünknek megfelelően a különböző domborzati viszonyok befolyásolják a víz lefutását. A tanulók feladata, hogy maguk népesítsék be a várost, és mindezt háromfós csapatokban.

A tanulók hipotézist állítanak fel háromféle, River Cityben megjelenő betegséggel kapcsolatban (vízben terjedő, levegóben terjedő és rovarok által terjesztett betegségek). A háromféle betegség történelmi, társadalmi és földrajzi kontextusba van beágyazva, így a diákoknak a valóságos kutatásokhoz hasonlóan komplex környezetben megjelenő kusza jelenséghalmazon kell vizsgálódnia. A projekt végén a diákok összehasonlítják saját kutatásukat a többi csoportéval, így számos további hipotézist és megközelítési módot is megismernek.

A River City-t játszó középiskolás diákok egy csoportját vizsgálták (Dede et al., 2005). A megfigyelések és kutatás alapján a játékosok szignifikánsan jobban teljesítettek biológiából a többieknél. A River City-t használó osztályok magasabb elköteleződést mutattak a reál tárgyak terén, magasabb részvételi arány mellett. 
A tudományos gondolkodás készsége nem alakul ki magától, így oktatási és kulturális eszközökkel kell támogatni kialakulását (Morris et al., 2013).

A videójátékok olyan kulturális eszközöknek tekinthetők, amelyek a tudományos jártasság három fő területét tudják támogatni: a tényanyag elsajátítását, a feldolgozási készségeket és a tudomány természetének megértését.

A számítógépes játékok számos más területen is jól használhatók ismeretek, illetve készségek megszerzésére. Jelen trendek szerint is leggyakrabban az oktatás területén használnak videojátékokat a szórakozáson túlmutató célkitüzésekkel (Hamari et al., 2014).

\section{A JÁTÉKOSÍTÁS HATÉKONYSÁGÁNAR MÉRÉSE}

A trendek azt mutatják, hogy világszerte egyre nő azoknak a cégeknek a száma, akik gamifikációs szolgáltatásokat nyújtanak. Komoly térnyerés tapasztalható oktatási, szervezetfejlesztési és marketing területen. De vajon mennyire igazolt a gamifikáció hatékonysága?

Fontos tudnunk, hogy a gamifikáció pozitív hatásai sok esetben kimutathatóak, de nagyban függnek a gamifikált kontextustól, illetve a játékosított folyamat felhasználóitól (Hamari et al., 2014) Ezt a pozitív hatást azonban csak akkor érhetjük el, ha komplex, jól átgondolt módon próbálunk tiszta célokat kitüzni magunk elé. A témakörben elérhető tanulmányok döntő hányada pozitív eredményekről számol be a megfigyelt motivációs elemek kapcsán, például a toplisták (leader board), trófeák (achievement), kitüzők, szintek, kerettörténet, egyértelmü cél, visszajelzés, jutalom, fejlődés, kihívás tekintetében.

Bizonyos szerzők (Hamari, 2013; Farzan és mtsai, 2008) úgy találták, hogy a gamifikáció pozitív hatásai pusztán az újdonságnak tudhatók be, hosszú távú hatást nem tud kiváltani. A folyamatos újdonság hatás elérése azonban segíthet azon, hogy újabb és újabb élményekre vágyjanak az emberek. A sport és mozgás világa, a változatossága miatt egyértelműen jobb táptalajt biztosítana a játékosítás eszközeinek.

Az oktatás/fejlesztés célú gamifikációs vizsgálatoknál többnyire megnövekedett motivációs és elköteleződési szintet találtak. Ugyanakkor hátrányként említették a fokozódó versengést (Hakulinen et al., 2013). Domínguez és munkatársai (2013) cikkükben a gyakorlati feladatokban nyújtott teljesítmény emelkedése és a magas szintű kezdeti motiváció mellett az írásbeli feladatokban nyújtott rosszabbodó teljesítményről és az órai aktivitás csökkenéséről számoltak be. Véleményem szerint ez az eredmény magyarázható a társadalmunkban is megfigyelhető hatással.

Akik a folyamatos újabb és újabb szórakoztató impulzusokhoz szoktak, azok nagyon nehezen térnek vissza a hagyományos, szürke hétköznapi módszerek világába, ahol úgy érzik, nem tudnak kiteljesedni. Ez megfigyelhető a gamereken (olyan játékosok, akik csak a játék öröméért játszanak), de a tömegközlekedéssel utazó emberek nagy százalékán is, akik nem képesek nem a telefonjukat nézve újabb impulzusok után keresgélni. Számukra a megszokott útvonalon, sokszor megszokott utazóközönséggel való haladás unalmas és szürke, míg a virtuális térben folyamatosan új dolgokra lelhetnek. Ezt a hatást semmiképpen sem skatulyázhatjuk a pozitív vagy negatív erók közé, de mindenképpen számolnunk kell vele.

A gamifikált célú játékok hatékonyságának tesztelése során az általánosan bevett kísérleti dizájnt, az előteszt - képzés/fejlesztés - utóteszt formát kell követnünk (Girard et al., 2012). A kontrollcsoport meghatározására nincs általánosan elfogadott szabály. Három különböző eljárásra van lehetőség:

1. a kontrollcsoport tagjai semmilyen képzést/fejlesztést nem kapnak,

2. a kontrollcsoport tagjait tradicionális módszerekkel oktatják/fejlesztik és

3. a kontrollcsoport tagjait egy azonos célra fejlesztett másik játékkal képzik/fejlesztik.

Girard és munkatársai kutatásaik alapján a hatékonysági tesztek során minimum két kontrollcsoportot javasolnak: egy képzésben/fejlesztésben nem részesített csoportot, illetve egy alternatív módszerrel fejlesztett csoportot.

A hatékonyság vizsgálatánál fontos megemlíteni, hogy Lieberoth (2015) kutatásának eredménye alapján a keretezés, a kerettörténet a pszichológiai hatás jelentős részéért felelős.
Tehát ha egy folyamatot nem dolgozunk át részleteiben, csak játék „köntösébe bújtatjuk”, úgy is jelentős hatást érhetünk el, míg a fejlesztéshez szükséges idő és költség jelentősen csökken.

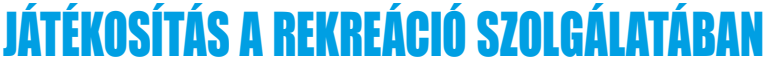 - KULCSTÉNYEZÖK A TAPASZTALATOK ALAPJÁN}

A fiatal generációnál különösen nagy problémát jelent, hogy mozgásra bírjuk óket. A mindennapos testnevelés bevezetése egy pozitív lépés, azonban ha nem sikerül megszerettetni a mozgást a gyerekekkel, akkor amint nem látjuk őket, passzivitásba temetkeznek. Miért ne építhetnénk bele a mozgásukba az amúgy is kiemelkedő figyelemmel övezett mobileszközöket? Egy-egy applikációs rendszer lehetőséget ad már meglévő tartalmak módosítására, sőt akár a saját tartalmaink elkészítésére is.

Egy-egy ilyen játékosított tartalommal ellátott program - a remek szórakozási lehetőség mellett - akár komoly kihívásokkal is kecsegtet a játékosok számára, melyek segítségével, ha a kihívás-készség egyensúly megteremtődik, jelentős sikerrel és pozitív élményekkel távozhatnak a résztvevók egy-egy programról. A sikeres játékok létrehozásához azért néhány alapszabállyal tisztában kell lennünk a játékok megalkotásakor. A készülékek teljesítménykülönbségeiból adódó tényezők miatt, ha minden egyes alapelemet nem is tudunk beépíteni, azért érdemes jó párat figyelembe venni, ahhoz, hogy élvezetes és motiváló legyen a játék.

1. Narratíva: szükséges a megfelelő háttértörténet megteremtése.

2. Visszajelzések: folyamatos visszajelzések szükségesek a játékosok irányába.

3. Reputáció, helyezések, szintek: a játékosoknak egyértelmúen el kell tudniuk helyezni magukat egy ranglistán.

4. Világos szabályok között kialakított versenyhelyzet: minden játékos alapvetően nyerni szeretne, azonban az fontos, hogy bízzanak a játék szabályrendszerében, és annak segítségével, a szabályok betartásával akarjanak nyerni.

5. Csapatok: lehetőséget kell adni csapatok kialakítására, amelyben a csapattagok szorosan együttmúködve tudnak mások ellen „küzdeni”. A játékokban létrehozott csapatok nagyban segítik a szociális interakciók kialakulását.

6. Kommunikáció: a játékosoknak lehetőséget kell biztosítani az egymás közti kommunikációra, legalább egy, de lehetőleg több csatornán.

7. „Idő nyomás”: Definiálnunk kell a játék hosszát, de ezt világosan mindenki számára láthatóan és elérhetően kell megtennünk.

Egy jól kialakított, átgondolt és mindenki számára kihívásokat biztosító (akár) csapatjáték hatalmas teret biztosít a rekreációs lehetőségeknek.

\section{GYAKORLATI PÉLDÁK A REKREATIU JÁTÉEOK ALKALMAZÍSŚRA}

A következőkben két gyakorlati példán keresztül szeretném bemutatni egy ilyen szervezett, rekreatív jellegü játék előnyeit.

\section{MÓDSZEREK}

A két csoport tagjai (30 fó) egy környezettudatosságra alapozó, GPS alapú, kvízkérdések beépítésével létrehozott pontvadász játékon vettek részt, melyet saját okostelefonjaikon futtattak. A tiszta játékidő/részvételi idő 35 perc volt. A játékosok helyzeti és mozgási adatait a készülékekbe épített, automatizáltan adatokat gyüjtő helymeghatározó rendszer biztosította, mely mára legalább 8-10 méteres pontossággal képes meghatározni a tulajdonosának pontos földrajzi helyzetét. A program végén a GPS segítségével mért helyadatokból kiszámolt távolságokat a készülékek automatikusan feltöltötték a szerverre, ahol egy grafikonon jelentek meg.

Az első program helyszíne egy a Velencei-tó mellett lévő arborétum kijelölt, enyhén lankás területe. A felső tagozatos diákok egy közeli általános iskolából érkeztek, és mindannyian rendelkeztek saját okostelefonnal. Néhány telefonon nem volt elegendő hely a játékhoz, azonban egy-egy, csupán grafikával szemet gyönyörködtető játékot minden kérlelés nélkül töröltek a gyerekek, csak hogy csatlakozhassanak a közös aktivitáshoz. 
A játék egy roppant egyszerü GPS alapú edukációs egyéni pontgyưjtő játék volt, a területen belül. A játékosoknak virtuális szemétkupacokat kellett begyüjteniük ahhoz, hogy pontokat szerezzenek. Megfelelő mennyiségű szemétkupac meglátogatása után ellátogathattak a szelektív hulladékgyújtő helyekre. A jó döntéseikért cserébe pontokat kaphattak, melyek segítségével lépdelhettek előre a ranglétrán.

A játékterületen belül elhelyezett kvízkérdésekre is ellátogathattak, melyek csupa fenntarthatósági és zöld gondolkodásmóddal, tudásanyaggal kapcsolatos kérdést tartalmaztak. Természetesen a helyes válaszért pont járt.

A játékban ebben az esetben 13 játékos vett részt, akik 35 percig tudtak egy körben játszani. A játékban természetesen egy oktató is részt vett, aki főleg beszélgetéssel töltötte az időt így a legkevesebb pontot ő szerezte, valamint a legkisebb távot is ő tette meg.

Második példánk egy, a Budai Várnegyedben játszódó történelmi játék, ahol 3 csapatban a csapattagoknak folyamatosan együtt dolgozva kellett bejárniuk a környéket, különböző virtuális és nem virtuális információk után.

A német nyelvű gimnazista csoport egy történelmi, pontvadász játék segítségével járhatta be a történelmi helyszíneket a Budai Várnegyedben, a telefonjukba épített GPS készülék és egy letöltött applikáció segítségével. A program 3 órás limitidővel rendelkezett, így bőven volt lehetőség a városnézésre és a játék feladatainak megfejtésére is. A játék végén egy rejtett kincsesláda várta a résztvevőket, melyet közösen együtt minden rejtvény összerakása után tudtak kinyitni.

\section{EREDMÉNYEY}

A játékosok összesen 25 ellenőrzőpontot tudtak meglátogatni, de nagyon fontos, hogy egy ellenőrzőpont mindössze 3 látogatás után végleg eltűnt. A „céltalan” rohangálás helyett tehát komoly taktika kellett ahhoz, hogy mindenki a lehető legtöbb pontot gyüjthesse.

A játékosok - a szabályok értelmezése után - a tiszta 30 perces játékidő alatt átlagosan 4,8 km-t tettek meg, sétálva, futva, kocogva, meg-megállva, miközben kérdésekre válaszoltak, kérdésekre keresték a választ az interneten, és a saját logikájuk szerint haladtak előre, versenyhelyzetben.

Ez az adat akkor lehet igazán érdekes, ha az eredményeket egy teljesen egyszerű Cooper teszttel hasonlítjuk össze. A 13-14 éves korosztályban a 12 perc alatt megtett 2700 m már kiváló eredménynek számít!

Ennél is érdekesebbek azok az adatok, melyeket 2016 és 2017 között gyüjtöttek a Stanford Egyetem kutatói. A kutatás több mint 700 ooo résztvevő segítségével készült, és az derült ki belőle, hogy a világon átlagosan 4961 lépést tesz egy ember egy nap folyamán. Ez a szám Magyarországon 5300-5500 lépés között van. A játékban részt vevő gyerekek ezt feltehetően jelentősen túlteljesítették, mivel nem 1 méter a lépéshosszuk.

A második játék a várnegyedben 3 óra hosszáig tartott, és átlagosan több mint $7 \mathrm{~km}$-t sétáltak a résztvevők a játékosított, történelmi, kincskereső kaland közben. Ezek a számok egyértelműen azt mutatják, hogy a mozgásra való hajlandóság sokkal magasabb, ha játékos környezetet teremtünk a résztvevők számára.

\section{KÖUETKEZTETÉSEY}

A játékosítás most már egyre több szolgáltatásba megérkezik, így egyre nagyobb teret nyer magának a fizikai aktivitásra alapozó alkalmazásokon belül is.

A fizikailag aktívabbak számára a különböző naplózó és egyéb funkciókkal ellátott applikációk közül elég csak a legnépszerúbb sportnaplózóra gondolnunk, ahol szinte minden héten részt vehetünk valamiféle kihíváson, akár egyedül, akár csapatban kívánjuk kerékpárral megmászni a Mount Everestet, vagy versengünk a legsportosabban munkába járók országos kihívásában.

Ennél extrémebb megoldások is léteznek, ahol például a tv-sorozatok divathullámát meglovagló élóhalott hordák elól menekülhetünk (mindenképpen futva).
A játékok segítségével a résztvevők könnyen elérhetik azt a flowélményt, amely a rekreáció egy nagyon fontos eleme, és ezen keresztül eljuthatnak egy autotelikus élményhez, mely a mozgás, a játékos aktivitás élvezete és keresése, az ez iránti igény felé mozdíthatja őket.

\section{FELASZNÁLT IRODALOM:}

Csíkszentmihályi, M., \& Szabó, E. (2001). Flow: az áramlat, a tökéletes élmény pszichológiája. Akadémiai.

Csikszentmihalyi, M., Abuhamdeh, S., Nakamura, J.: Flow. In: Dweck, C.S., Elliot, A.J. (eds.) Handbook of Competence and Motivation, pp. 598608. Guilford Press, New York (2005)

Dede, C., Clarke, J., Ketelhut, D. J., Nelson, B., \& Bowman, C. (2005, April). Students' motivation and learning of science in a multi-user virtual environment. In American Educational Research Association Conference, Montreal, Canada.

Domínguez, A., Saenz-de-Navarrete, J., De-Marcos, L., Fernández-Sanz, L., Pagés, C., \& Martínez-Herráiz, J. J. (2013). Gamifying learning experiences: Practical implications and outcomes. Computers \& Education, 63, 380-392.

Farzan, R., DiMicco, J. M., Millen, D. R., Brownholtz, B., Geyer, W., \& Dugan, C. (2008). When the experiment is over: Deploying an incentive system to all the users. In Symposium on Persuasive Technology.

Fritz P., Andó R., Bibarc T., Kocsis Cs., Magyar M., Patakiné Bősze J., Ungvári M., (2019): Alapfogalmak és jelentések a rekreáció területén, Miskolci Egyetemi Kiadó (2019) 29-40.

Girard, C., Ecalle, J., \& Magnan, A. (2012). Serious games as new educational tools: how effective are they? A meta囚analysis of recent studies. Journal of Computer Assisted Learning, 29(3), 207-219.

Hamari, J. (2013). Transforming homo economicus into homo ludens: A field experiment on gamification in a utilitarian peer-to-peer trading service. Electronic commerce research and applications, 12(4), 236-245.

L. Hakulinen, T. Auvinen, and A. Korhonen, „Empirical Study on the Effect of Achievement Badges in TRAKLA2 Online Learning Environment", In Proceedings of Learning and Teaching in Computing and Engineering (LaTiCE) conference, March 21-24, 2013, Macau, pp. 47-54.

Hamari, J., Koivisto, J., \& Sarsa, H. (2014, January). Does gamification work?-a literature review of empirical studies on gamification. In System Sciences (HICSS), 2014 47th Hawaii International Conference on (pp. 30253034). IEEE.

Kishore Kumar Damodaran, Vanshika Sharma, Senthil Purushothaman * (2019). Relationship between the hand discomfort with the dimensions of hand and touch screen mobiles RJHS Rehman Journal of Health Sciences. Vol. 01, No. 01, 2019 3-5.Shamaal Khattak1, Mashal Gul2 , Hoor Ali Kakar3 , Ghazanfar Ullah4, Mujeeb Ur Rahman5 (2018). The cost of long-term use of smart phones in the form of text neck syndrome; a systematic review

Kovács Tamás Attila (2004). A rekreáció elmélete és módszertana (Fitness Kiadó) 39-41.

Lieberoth, A. (2015). Shallow Gamification Testing Psychological Effects of Framing an Activity as a Game. Games and Culture, 10(3), 229-248.

Morris, B. J., Croker, S., Zimmerman, C., Gill, D., \& Romig, C. (2013). Gaming science: the "Gamification" of scientific thinking. Frontiers in psychology, 4.

Nakamura, J., \& Csikszentmihalyi, M. (2002). The concept of flow. Handbook of positive psychology, 89-105.

Nelson, B., Ketelhut, D. J., Clarke, J., Bowman, C., \& Dede, C. (2005). Design-based research strategies for developing a scientific inquiry curriculum in a multi-user virtual environment. Educational Technology, 45(1), 21-27.

Reeves, B. \& Read, J. L. (2010). Ten Ingredients of Great Games. Letöltve: December 1, 2015, from: http://www.cedma-europe.org/newsletter $\% 20$ articles/misc/Ten\%20Ingredients\%20of\%20Great\%20Games\%20(Apr\%20 10).pdf

Ryan, R. M., \& Deci, E. L. (2000). Intrinsic and extrinsic motivations: Classic definitions and new directions. Contemporary educational psychology, 25(1), 54-67.

Ryan, R. M. \&,Deci, E. L. (2000). Self-determination theory and the facilitation of intrinsic motivation, social development, and well-being. American Psychologist, Vol 55(1), Jan 2000, 68-78.

Statisztika a magyarországi digitalizációról From: https://bitport.hu/ ujabb-statisztika-a-magyarorszagi-digitalizaciorol (Letöltve: 2020.02.04)

Magyar okostelefonozók és mobilnetezők száma From: https://www. origo.hu/techbazis/20190907-magyar-okostelefonozok-mobilnetezok-szama.html (Letöltve: 2020.02.04)

Mennyit lép egy ember egy nap From: https://ng.hu/tudomany/2017/07/14/kiszamoltak-mennyit-lep-egy-ember-egy-nap/ (Letöltve: 2020.02 .04 )

Játék és Tanulás From: http://www.jgypk.hu/mentorhalo/tananyag/ Jatekpedagogia/72_jtk_s_tanuls.html (letöltve: 2020.05.03) 